\begin{tabular}{|l|l|l|}
\hline \multicolumn{2}{|c|}{ PublisherInfo } \\
\hline \hline PublisherName & $:$ & BioMed Central \\
\hline \hline PublisherLocation & $:$ & London \\
\hline \hline PublisherImprintName & $:$ & BioMed Central \\
\hline \hline
\end{tabular}

\title{
Useful resources at the University of Pittsburgh Critical Care Division website
}

\begin{tabular}{|l|l|l||}
\hline \multicolumn{2}{|c|}{ ArticleInfo } \\
\hline \hline ArticleID & $:$ & 4283 \\
\hline \hline ArticleDOI & $:$ & $10.1186 /$ ccf-2000-webreport1466 \\
\hline \hline ArticleCitationID & $:$ & webreport1466 \\
\hline \hline ArticleSequenceNumber & $:$ & 24 \\
\hline \hline ArticleCategory & $:$ & Web report \\
\hline ArticleFirstPage & $:$ & 1 \\
\hline \hline ArticleLastPage & $:$ & 3 \\
\hline \hline & & RegistrationDate : 2000-4-13 \\
\hline ArticleHistory & $:$ & OnlineDate \\
\hline \hline ArticleCopyright & $:$ & Current Science Ltd2000-13 \\
\hline \hline ArticleGrants & $:$ & \\
\hline \hline ArticleContext & $:$ & 1305444 \\
\hline \hline
\end{tabular}




\section{Overview}

This site has clearly been carefully developed to be of use to both internal users of the site, and visitors from outside. As well as the navigation system (arranged across the top of the page) the home page contains a faculty listing that is hyperlinked to short biographies of the individual members. The majority of the homepage is taken up with a mission statement from Professor Mitchell Fink.

The ongoing research programs are a source of much pride to the division. Each particular area of research (various aspects of sepsis, brain death, outcomes and healthcare management) is outlined, and the investigators and resulting publications are listed.

The education program is comprehensively covered with curricula for fellowships in Surgery, Anesthesia, Internal Medicine and Pediatrics all available online. There are contact details (email and phone numbers) for the program directors as well as information on entry requirements for the program.

There is a resources section containing a variety of links to external sites. This is well presented, and it may be worth investigating as the links appear to have been carefully selected.

The journal club section is a real highlight. Articles are assessed according to a standardised methodology (which is detailed) and are then published on the site. To date, the written extracts of 15 journal clubs are available. The evidence-based analysis and presentation of these extracts make this section worth returning to, particularly as there is a calendar of the forthcoming journal clubs, allowing the visitor to schedule their return.

\section{Content}

This site introduces the aims of the division, details the various research programs, outlines the educational opportunities and manages to provide a number of useful resources to outside visitors. Its elegant interface, combined with the excellent journal club, makes this site well worth visiting.

Information not available

None 


\section{References}

1. University of Pittsburgh Critical Care Medicine (CCM) Division. [http://www.anes.upmc.edu/mcctp/ index.html]

This PDF file was created after publication. 